\title{
Effect of Guerrilla Marketing on Guerrilla Entrepreneur Performance: A Study of Selected Businesses in Nigeria
}

\author{
Kabir Adeniyi Yagboyaju ${ }^{1}$, Ikwuagwu Henry Chinedu ${ }^{2}$ \\ ${ }^{I}$ Department of Marketing Management, Nile University of Nigeria, Nigeria \\ ${ }^{2}$ Department of Banking and Finance, Michael Okpara University of Agriculture, Umudike, Nigeria
}

\begin{abstract}
This research study empirically assessed the effect of guerrilla marketing on guerrilla entrepreneur performance focusing on selected businesses in Nigeria. The study adopted survey research design which suites the research because of its descriptive nature. Multiple regression analysis using ANOVA was adopted to analyse the variables in the models under study. The result indicate that there is a positive relationship between Entrepreneur Performance (ENTP) and Ambient Marketing (ABTM) with a coefficient values of 0.621 . Statistically, the Sig. value of 0.021 is lower than the acceptable significance value of 0.05. Also, Ambush Marketing (ABSM) has coefficient value of 0.685. Statistically, the Sig. value of 0.003 is lower than the acceptable significance value of 0.05. Furthermore, Sensation Marketing (SSNM) was observed to be positively related to Entrepreneur Performance (ENTP) with a coefficient value of 0.788 and a Sig. value of 0.017 . Finally, Viral Marketing (VILM) has a coefficient value of 0.591 and a Sig. value of 0.448, indicating that VILM has a positive but insignificant effect on ENTP. We therefore conclude that for the guerrilla entrepreneur in Nigeria to be successful and sustain his business, he must show and implement empathy in his business. Also guerrilla entrepreneur must engage in publicity that is creative, innovative, and attractive even in terms of cost like the guerrilla marketing strategy.
\end{abstract}

Keywords: Guerrilla Marketing, Entrepreneur Performance, Ambient Marketing, Sensation Marketing, and Viral Marketing

\subsection{INTRODUCTION}

The term Guerrilla Entrepreneur is a concept developed by Jay Conrad Levinson through his works on guerrilla marketing. The broader idea of guerrilla marketing was first introduced in his 1984 book, titled 'Guerrilla Advertising'. Although, the concept of guerrilla marketing initially struck himin 1957 when, as a U.S. Army counter-intelligence analyst, he was required to write reports of investigations. That taught him to be concise. It also led him to begin a career in advertising. The term guerrilla marketing and guerrilla entrepreneur were inspired by Guerrilla warfare which is a form of irregular warfare and relates to small tactic strategy used by armed civilians. Some of the Tactics used are ambushes, sabotage, raids and elements of surprises. According to Van Den Putte (2009) popularity of Guerrilla concept has been growing steadily because of the decline in Classical Advertisement due to the situation of an average American consumer, who is exposed to an average of 3000 advertising message in one day, and secondly consumers are becoming used to same advertisement repeatedly, thereby becoming 'too familiar' (Kimmel 2005).

Jay Conrad Levinson (2011) said that the guerrilla entrepreneur knows that the journey is the goal. He also realizes that he is in control of his enterprise, not the other way around, and that if he is dissatisfied with his expedition, then he is missing the point of the journey itself. Unlike the conventional enterprises, which often required huge sacrifices for the sake of the business objective, guerrilla enterprises place the goal of a pleasant business adventure ahead of the mere notion of sacrifices. Marketing is key to every business venture, and conventional advertising requires adequate funding which a start-up business may not be able to provide considering the various contending demands; hence incurring huge bills on advertising may not be appropriate, particularly for an entrepreneur. 


\subsection{LITERATURE REVIEW}

\subsection{Concepts Associated with Guerrilla Marketing}

\subsubsection{Guerrilla Marketing Instruments}

Guerrilla marketing means going after the conventional goals of profits, sales and growth but doing it by using unconventional method at exceptionally low budget (Curzon \& Jones, 2019; Entrepreneur, 2019).GM does not suggest the usage of direct sales discount, but rather attracts patronage by utilizing completely different and nontraditional tools (flash, mobs, stickers, bombing, graffitietc.) (Alena 2012). The objective of GM is to draw a long-lasting impression on people, and it is achieved by evoking a surprise effect and diffusion effect while keeping the costs low; with this, different marketing instrument are used(Hutter\& Hoffman 2011).

Ambient Marketing: Ambient advertising creates possibilities of interaction with the recipient by evoking miscellaneous emotions and feelings and it is often referred to as a non-standard promotion tool. Ambient promotion creates a positive impression around the advertise creation. They are referred to as innovative and hilarious. Thus, ambient marketing includes innovative advertising at strange locations e.g., on buses and trains, postcards, even toilet seats in pubs or in restaurants (Rudzewicz \&Grzybowska-brzezińska, 2013).

Ambush Marketing: Ambush marketing is defined as the practice whereby another company, often a competitor, intrudes upon public attention surrounding the event, thereby deflecting attention toward themselves and away from the sponsors (Piątkowska \& Gocłowska, 2016). Ambush marketing is understandably controversial, given that this type of advertising forms an essentially fraudulent association with an event.

Sensation Marketing: Sensation marketing again involves unusual actions or spectacular demonstrations carried out, for example, at the point-of-sale. The marketing act thus operates as a promoter or multiplier. Examples of sensation marketing include surprise fashion shows or flash-mobs in pedestrian zones (Textbroker.com, 2021).

Viral Marketing: Viral marketing is also associated with guerrilla marketing; the idea involves being able to rapidly attract the greatest amount of attention within your target group. Viral marketing aims to spread content virally across a consumer population by personal, word-of-mouth recommendation, or online sharing via social media (Nufer, 2013).

\subsubsection{Guerrilla Marketing Drivers \\ Surprise effect}

Rationale: The core principle of the guerrilla approach is to surprise consumers with unexpected activities to draw their attention to the advertising message. Surprise is because of the divergence of perceptions and expectations. Consumers, who are surprised by unexpected advertisements, can hardly avoid processing the advertising message (Hutter\& Hoffmann, 2011). In this way, the revelation effect helps to attract the attention of consumers who try to obviate being exposed to advertisements.

Instruments: Ambient advertising is a creative, innovative form of outdoor advertising that explicitly intends to surprise consumers by placing unexpected advertisements at unusual locations(Hutter, 2015).

Sensation marketing aims at surprising pedestrians in public places by actions that go beyond the scope of familiarity (Hutter\& Hoffmann, 2011). Passers-by look at a specific action, because it is unconventional and spectacular (e.g., dancers performing in front phone shops in Computer Village in Lagos to attract attentions to the shop). Ambient and sensation marketing have something in common; both dumbfound consumers in their familiar environments.

\section{Diffusion effect}

Rationale: Guerrilla marketing basically aims at stimulating diffusion effect. Viral marketing is an approach which initiates process that spreads like a virus among potential consumers; marketers can diffuse advert messages directly or through indirect communication. Such marketing strategy is stimulated by innovative information and technology adoption, many of the advertising messages are triggered to diffuse and spread across in short time with greater implication and participation (Katke, 2016). Therefore, guerrilla marketing provides ways of increasing the number of individuals exposed to the advertising without increasing the cost of a campaign. 
Instruments: Viral marketing consists of different methods of starting a communication process which spreads wide among targeted customers. Stimulated by innovation in information and communication technologies, many new techniques of viral marketing have evolved during the last few years. Video clips which diffused throughout the World Wide Web, are the most frequently applied method of viral marketing, and others off the internet are "word of mouth", "network marketing", etc.,(Deepa \&Thenmozhi, 2014).

\section{Low cost effect}

Rationale: Two type of guerrilla campaign evoke a low-cost effect. First, the diffusion effect helps to reach a wide audience causing no or little costs, because consumers (viral marketing) or the media (guerrilla PR) pass on the advertising message. Second, guerrilla campaign is regularly implemented in such a manner that they require little monetary efforts e.g., a "free riding approach".

Instruments: Ambush marketing is the most prominent distinct guerrilla instrument that focuses on keeping expenditures on a low level. It explicitly builds on a free riding effect most often shifting attention to themselves instead of the sponsors (Hutter\& Hoffmann, 2011).

\subsubsection{Guerrilla Entrepreneur in Nigeria}

The concept of guerrilla entrepreneur, like most other $20^{\text {th }}$ century phenomena, is not in any way strange to most Nigerian entrepreneurs as they deploy it in their quest to see their investment grown unconventionally. Several successful examples of guerrilla entrepreneurship abound in the education sector of the Nigerian society and market space. The education sector remains an extremely attractive area of investment for Nigerian entrepreneurs, as the public schools at the primary, secondary, and tertiary levels remained highly inadequate. It is disturbing to note that presently, more attention has been shifted from the public to the private universities in Nigeria (Akindele, 2013).

There has been a significant increase in the number of private universities since 1999 when Igbinedion University, Okada - the first private university in Nigeria was established (Akindele, 2013). Over the years, government has continually provided the enabling environment for entrepreneurial initiatives in virtually all sectors of the economy. In education, the upsurge of private initiatives in secondary and tertiary education in recent past may have begun to put the heat on publicly funded institutions to return to the drawing board, restructure and realign their curricula to meet contemporary exigencies (Odeleye, et al. 2012).

The guerrilla entrepreneur in the educational sector has continued to master the act of ensuring success while still enjoying what they are doing without stress. With the deplorable state of most public schools at all levels, the privately owned schools work on how to improve the standard of services provided to the students. The private entrepreneur is concerned with what to do to attract more students to join their school and how to step up the range of courses being offered to take over more of the market share of the education business (Odeleye, et al. 2012).

For private ownership to be seen as alternative way of engendering better performance and better products that could meet the challenges of the world of works, the guerrilla entrepreneurs have an upbeat attitude towards the challenges by making efforts on such areas like: maintaining discipline among the staff and students; creating conducive environment for learning; providing appropriate teaching facilities; encouraging moral conducts among students; improving the student-teachers ratio; promoting motivations and rewards for excellent performance; etc.

Therefore, the role and positive impact private universities had on the education and socio-economic development of Nigeria can-not be overemphasized (Olawore \& Ajayi, 2016). This is the whole essence of the guerrilla entrepreneur's presence in business in the first instance as he is always prepared; his plans foresee barriers and reveal precisely how to overcome them (Levinson, 2011).

As of 2009, the number of privately owned universities in Nigeria was 64 while publicly owned universities (at the federal and state levels) were 62 . This implies that the privately owned university accounted for slightly over $50 \%$ of the entire university institutions in the country then (Akindele, 2013). This is so because a guerrilla entrepreneur, which the school owners are, has ever-present confidence. 


\subsection{Empirical Review}

Isaac (2014) examined the impact of the integration of guerrilla with traditional marketing on small to medium scale enterprises performance, by testing the hypotheses in the context of marketing hotel services in Owerri, Imo State Nigeria. The study applied survey and descriptive research approach, using two questionnaire types to gather data on productivity of organizational marketing, and integration of guerrilla marketing and traditional marketing. To test the hypotheses, correlation method was adopted to determine the relationship between integration of guerrilla and traditional marketing and the improvement of hotel productivity in Nigeria. Stratified random sampling technique was used in selecting 70 respondents who are managers of the hotels. The independent variables include new methods of advertisement, innovation and problem-solving techniques, new communication technologies, marketing budget while the dependent variable is the productivity of organizational marketing research. The findings show that guerrilla marketing is complementary to traditional marketing. The study therefore recommended GM as a paradigm for hotel enterprises in Owerri; hence, guerrilla marketing is the survival technique to adopt for the unstable hostile business environment in which the hotels operate.

Navrátilováa and Milichovskýa (2015) assessed the impacts of the marketing communication trends of guerrilla marketing on customers of large enterprises and SMEs based on gender, by testing the hypotheses in the context of beverages, food, sport/entertainment, and beauty products' companies in Czech Republic. The study used both ex post facto and primary data approaches. Questionnaire was administered on 199 respondents who were students at Brno University of Technology for primary data. The data gathered were processed using the statistical program IBM SPSS Statistics 20, and the dependency between the two nominal variables was subsequently analysed by means of contingency tables and Pearson's chi-squared test. The result of the research shows that guerrilla marketing campaigns bring big competitive advantage for each small and medium company in the Czech or Central European market.

Akhtar et al. (2016) investigated the impact of guerrilla marketing on consumer buying behaviour, by testing the hypotheses in the context of the tobacco industry in Okara, Pakistan.

Primary data was sourced using Likert 5-point scale structured questionnaire administered on 200 respondents drawn from university and colleges of Okara city. The variables considered in this study include is Guerrilla marketing (independent variable), and Consumer buying behaviour (responding variable). The study was analysed using linear regression analysis on the SPSS software. The findings of the study show that there is a positive relation between the variables. The results showed that guerrilla marketing has a significant impact on consumer buying behaviour, most respondents says that guerrilla marketing is a creative and effective strategy. Guerrilla marketing therefore is seen to fulfil the needs and wants of customers, because customers are always demanding new and innovative things in the market; and these things are fulfilled by guerrilla marketing.

Okwara et al. (2017) examined the impact of Guerrilla Marketing on the Sales Performance of entrepreneurs, by testing the hypotheses in the context of entrepreneurs at Alaba International Market Lagos, Nigeria. The study adopted survey method, using Likert Scale structured questionnaires to gather data from the selected marketing enterprises within the market. A total of 80 respondents were used as the survey sample, and responses were obtained from 70 respondents. The data was analysed using basic statistical frequency percentage. The findings showed that guerrilla marketing is a marketing strategy that is used for advertising with a minimum budget; also, if not carefully presented guerrilla marketing can lead to series of risk that can make the targeted audience misinterpret the firm, which in turn will lead to decrease in sales. The study recommended that firms or entrepreneurs who are starting from the scratch should adopt guerrilla marketing strategies as it will assist to enhance their personal experience with the brand as well as build good reputation at a minimal cost.

Ladokun (2019) examined the impact of Entrepreneurial Marketing on business performance; the hypotheses were tested in the context of medium-size hotel businesses in Ibadan, Nigeria.

The data were collected through structured questionnaire administered to random sample size of 154 hotels and convenient sample of 2 senior staff from each of selected hotel. The responses generated were analysed using descriptive, regression and correlation statistical methods.

The study concluded that Entrepreneurial Marketing (i.e., Guerrilla Marketing strategies), as it is related to promotion, have significant impact on and relationship with performance (i.e., sales growth and brand image creation) of Medium-size hotel enterprises in Ibadan, Nigeria. The study recommended that Hotel Entrepreneurs should embrace Guerrilla Marketing because of its direct and positive impact which is cost effective. 


\subsection{METHODOLOGY}

The study adopts a survey research design method. The study used multiple regression approach to express the relationship among the variables. Uyanik and Guler (2013) opined that a multiple regression approach is a form of research method that involves collecting data on two or more variables independent and computing them to find the relationship or association that exists between the variables and a dependable variable. The major purposes of multiple regression design are to explore causal relationships between variables and to predict scores on one variable from research participant's scores on other variables. A highly structured questionnaire was used as instrument for data collection. The study geographical area was Nigeria, however, selected states from each six geo-political zones were sampled for data collection. Multiple regression analysis using ANOVA was adopted to analyse the variables in the models under study.

\subsection{Model Specification}

The model for the study is therefore stated thus in functional form:

Model

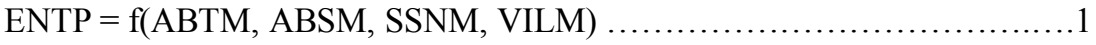

$\mathrm{ENTP}=\boldsymbol{\alpha}+\beta_{1} \mathrm{ABTM}+\beta_{2} \mathrm{ABSM}+\beta_{3} \mathrm{SSNM}+\beta_{4} \mathrm{VILM} \ldots \ldots \ldots \ldots \ldots \ldots \ldots .2$

To account for other indices not included in the model we introduce the stochastic variable.

$\mathrm{ENTP}=\boldsymbol{\alpha}+\beta_{1} \mathrm{ABTM}+\beta_{2} \mathrm{ABSM}+\beta_{3} \mathrm{SSNM}+\beta_{4} \mathrm{VILM}+e \ldots \ldots \ldots \ldots \ldots . . .3$

Where:

ENTP $\quad$ Entrepreneur Performance

$\mathrm{ABTM}=\quad$ Ambient Marketing

$\mathrm{ABSM}=$ Ambush Marketing

SSNM = Sensation Marketing

VILM $\quad=\quad$ Viral Marketing

$\alpha=$ slope, $\beta_{1}-\beta_{4}=$ Coefficients and $e=$ stochastic variable, which shows the influence of other indices affecting the dependent variable.

\subsection{Result and Findings}

Table 1.0

Model Summary

\begin{tabular}{|l|r|r|r|r|}
\hline Model & $\mathrm{R}$ & $\mathrm{R}$ Square & $\begin{array}{c}\text { Adjusted R } \\
\text { Square }\end{array}$ & $\begin{array}{c}\text { Std. Error of } \\
\text { the Estimate }\end{array}$ \\
\hline 1 & $.784^{\mathrm{a}}$ & .614 & .622 & 1.06386 \\
\hline
\end{tabular}

a. Predictors: (Constant), ABTM, ABSM, SSNM, VILM

Source: SPSS 20.0

Table 1.2 ANOVA $^{a}$

\begin{tabular}{|rl|r|r|r|r|r|}
\hline \multicolumn{1}{|l|}{ Model } & \multicolumn{1}{c|}{$\begin{array}{c}\text { Sum of } \\
\text { Squares }\end{array}$} & Df & Mean Square & F & Sig. \\
\hline \multirow{2}{*}{1} & Regression & 4.910 & 4 & 88.110 & 2177.381 & $.019^{\circ}$ \\
& Residual & 117.707 & 182 & 1.132 & & \\
& Total & 122.617 & 186 & & & \\
\hline
\end{tabular}

a. Dependent Variable: Entrepreneur_Performance

b. Predictors: (Constant), ABTM, ABSM, SSNM, VILM

Source: SPSS 20.0

Table 1.3

\section{Coefficients $^{\mathrm{a}}$}

\begin{tabular}{|c|c|c|c|c|c|c|}
\hline \multirow{2}{*}{\multicolumn{2}{|c|}{ Model }} & \multicolumn{2}{|c|}{ Unstandardized Coefficients } & \multirow{2}{*}{$\begin{array}{c}\text { Standardized } \\
\text { Coefficients } \\
\text { Beta }\end{array}$} & \multirow[t]{2}{*}{$\mathrm{T}$} & \multirow[t]{2}{*}{ Sig. } \\
\hline & & B & Std. Error & & & \\
\hline \multirow{5}{*}{1} & (Constant) & 1.322 & .400 & & 3.309 & .001 \\
\hline & ABTM & .621 & .197 & .602 & 13.441 & .021 \\
\hline & ABSM & .685 & .142 & .557 & 9.594 & .003 \\
\hline & SSNM & .788 & .065 & .721 & 5.952 & .017 \\
\hline & VILM & .591 & .081 & .518 & 1.543 & .448 \\
\hline
\end{tabular}

a. Dependent Variable: Entrepreneur_Performance 


\section{Source: SPSS 20.0}

The analysis result shown on Table 1.0, 1.2 and 1.3 above presents the result of the relationship between Entrepreneur Performance (ENTP) and various independent variables. The result of the regression estimates from Table 1.3 above indicate that there is a positive relationship between Entrepreneur Performance (ENTP) and Ambient Marketing (ABTM). This is evidenced by coefficient value of 0.621. Statistically, the Sig. value of 0.021 is lower than the acceptable significance value of 0.05 . This means that Ambient Marketing strategy significantly relate to entrepreneur performance. Also, Ambush Marketing (ABSM) has coefficient value of 0.685 . Statistically, the Sig. value of 0.003 is lower than the acceptable significance value of 0.05 . This means that ABSM is significantly related to ENTP. Furthermore, Sensation Marketing (SSNM) was observed to be positively related to Entrepreneur Performance (ENTP) with a coefficient value of 0.788 and a Sig. value of 0.017.Finally, Viral Marketing (VILM) has a coefficient value of 0.591 and a Sig. value of 0.448, indicating that VILM has a positive but insignificant effect on ENTP.

\subsection{Discussion}

Our study has shown that entrepreneur performance is differently influenced by various marketing strategies. Sustainable entrepreneur performance calls for all round marketing approaches which in turn could create an attractive atmosphere for entrepreneurship development. Marketing approaches essentially implies the consolidation and promotion of brands and the building of loyalty in the minds of diverse customers to increase market share and growth. More broadly clarified, it connotes integrated approach to address volatile tendencies at different phases of product cycle and development to achieve a meaningful and progressive performance. To achieve this, measures must be strategically structured and put in place for the benefit of everyone. Customer insecurity is a feeling of unprotectedness, vulnerability, unsafe and helplessness which hinder patronage and often time is the major cause of forceful product usage switching. Moreover, the link between customer insecurity and entrepreneur performance is a complex, but indisputable one.

The primary goals of adopting a marketing approach or mix are to reduce or possibly eliminate low patronage and to maintain brand name of the entrepreneur by eliminating the economic, social, environmental, political, and other conditions that generate threats to the promoting of customer patronage by anticipating and managing brand crises before they worsen.

However, there is no assurance that any of the marketing approach mix would always be effective and yield desired result in entrepreneur performance. Hence continuous evaluation of various approaches of marketing mix must be practiced. This is because many initiatives quickly break down as soon as external factors flares up sequel to socio-economic effects. This bring to fore the need for mangers to be proactive and promote strategic activities in the management of customers data for optimum entrepreneurial benefit.

\subsection{Conclusion}

The paper attempts to look at the concept of Guerrilla Marketing and Guerrilla Entrepreneur, and how they started and their unique features. The interconnection between the concepts. Recommendations are also provided for a guerrilla entrepreneur to success in a business environment like Nigeria, with specific consideration for the appropriate marketing strategy to adopt.

As earlier indicated, guerrilla entrepreneur is a unique form of entrepreneurship with peculiar attributes. He takes the positive enthusiasm about success with his adventure in business. Most guerrilla entrepreneur believes that goal of the business enterprise must be achieved but not at the expense of quality lifestyle of the entrepreneur and his family. The business goals are key to the survival of any business enterprise; and so it is, with guerrilla entrepreneurship. However, the guerrilla entrepreneur sees his involvement in any business as a refreshing and interesting endeavour that should not attract any stress; and that when it becomes stressful, then something is not right with the business model.

Meanwhile, it is almost impossible to discuss the concept of guerrilla entrepreneur without mentioning the instrumentality of its business model, like the guerrilla marketing. Guerrilla marketing remains an extremely attractive medium of drawing the attention of buyers to the business brand of goods and services, at a far reasonable cost than the conventional advertisement. The various arms of guerrilla marketing including digital marketing, ambush marketing, internet and online marketing provide great opportunities for both guerrilla and non-guerrilla entrepreneur to take great advantage of doing the age-long practice of marketing using the unconventional method. The critical idea about guerrilla marketing is all about the surprises that goes with it in 
terms of quick penetration of the market, low-cost implications, and the diffusion effect; all of which makes guerrilla marketing almost indispensable.

\subsection{Recommendation}

There are guerrilla entrepreneurs in every corner of the globe, Nigeria is not an exception. It has been observed that the commercial educational sector is one overly critical area of business that entrepreneurs have ventured into. Although, specific challenges have equally been identified with this concept and practice, as business owners particularly the wealthy profit-inclined individuals have stepped into the education business at the different levels of the educational system i.e., primary, secondary, and tertiary levels.

Therefore, some of the recommendations to be considered in having a successful guerrilla entrepreneurship in Nigeria include; Guerrilla entrepreneurship is all about love and affection for all, including the entrepreneur himself, his work, his family, his liberty, his friends, his customers and employees, his lifestyle etc. Hence, for the guerrilla entrepreneur in Nigeria to be successful and sustain his business, he must show and implement empathy in his business. Marketing is the spirit that brings attention and attraction to any business particularly when the marketing strategy is creative and innovative. Therefore, a guerrilla entrepreneur must engage in publicity that is creative, innovative, and attractive even in terms of cost like the guerrilla marketing strategy.

The guerrilla entrepreneur should avoid the pitfalls of typical entrepreneurs. Some of the pitfalls are the excessive overhead cost, burn-out syndrome, loss of personality and the humility in you, loss of focus etc. The guerrilla entrepreneur should also take good cognisance of the five factors that can make managing a business either easy to do or harder to handle. The five factors include time management, contact networking, change ("the only constant factor in life"), scouting for talent, and adopting the right technology.

\section{References}

[1] Akindele, I. (2013). Evolution of private universities in Nigeria: Matters arising and the way forward. Educational Research and Reviews, 8(2), $41-50$.

[2] Alokolaro, A. (2017). LocalizedDigital.Com 'An Analysis of Two Campaign that went Viral in Nigeria'.

[3] Barnes, J. (1999). Admap: Creating a difference with Ambient Media, 34.

[4] Benjamen, B. (2006). An investigation into the relevance of Guerrilla Marketing to small and medium-sized enterprises. Bachelor Thesis.

[5] Bolarinwa, E. (2015). Guerrilla Marketing Brand and Repositioning Strategy: A Crux on Creativity and Sales.

[6] Chamráth, A. (2016). Guerrilla Marketing: Analysis of A Practical Example. Faculty of Economics and Administration, Masaryk University.

[7] Curzon \& Jones (2019). A Guerrilla Marketing Agency. Retrieved from https://www.curzonandjones.com/blog/what-isguerrilla-marketing

[8] Deepa, N, \&Thenmozhi, S. (2014). Viral marketing as an on-line marketing medium. National Conference on "Innovative Business Practices in Technological Era", Erode Sengunthar Engineering College, Thudupathi, Erode, 88-94

[9] Delana (2008). Different types of Guerrilla marketing. Retrieved from: http// web urbanist.com/2008/06/19/

[10] Guerrilla marketing. Retrieved on $9^{\text {th }}$ April, 2021 from https://www.entrepreneur.com/encyclopedia/guerrilla-marketing

[11] Hutter, K. (2015). Unusual location and unexpected execution in advertising: A content analysis and test of effectiveness in ambient advertisements. Journal of Marketing Communications, 21(1), 33-47.

[12] Hutter, K. \& Hoffmann, S.(2011). Guerrilla Marketing: The Nature of the Concept and Propositions for Further Research. Asian Journal of Marketing, Vol. 5, (2)39- 54

[13] Katke, K. (2016). Guerrilla marketing for effective marketing communication: A special reference to social media marketing.Asia Pacific Journal of Research, I (41), 151 - 157.

[14] Levinson, J. \& Levinson, J. (2011). Guerrilla Marketing Remix. Entrepreneur Media Inc. USA.

[15] Luxton, S. \& Luxon, D.(2000). ANZMAC 2000 Visionary Marketing for the 21th Century: Facing the Challenge Evaluations. What is this thing called ambient advertising. Proceedings of, Nov. 28-3 Dec., Griffith University, Queensland, Australia, pp: 734-738.

[16] Martin, K. (2014). Guerrilla Marketing Concept and Further Research Possibilities. Silesian University in Opava, School of Business Administration in Karvina.

[17] Nufer, G. (2013). Guerrilla marketing_-Innovative or Parasitic Marketing? Modern Economy,4, 1 - 6. 
[18] Odeleye, D., Oyelami, O., \&Odeleye, O. (2012). Private ownership and educational management in Nigeria: Issues and Challenges. JORIND Vol.10 (2), $223-229$

[19] Okwara, C., Nkwocha, C.,\& Onyeme, L. (2017). The Impact of Guerrilla Marketing on the Sales Performance of Entrepreneurs (A Case of Alaba International Market).International Academic Journal of Management and Marketing; 9 (1).

[20] Olawore, O., \& Ajayi, T. (2016). The Emergence of Private Universities in Nigeria and Their Various Challenges. Journal of Applied Information Science and Technology, Vol. 9 (1) 30 - 38

[21] Piątkowska, M. \& Gocłowska, S. (2016). Classification of ambush marketing methods in sport - evidence from the 2012 UEFA European championship. International Journal of Contemporary Management, 15 (1), 131-146.

[22] Rudzewicz, A. \& Grzybowska-brzezińska, M. (2013).Ambient advertising of global brands. Retrieved on $14^{\text {th }}$ April, 2021 from https://www.researchgate.net/publication/283638341

[23] Ten top Adverts in Nigeria at the moment (2019). Retrieved from: http//Narametrics.com

[24] Text Broker.com. Content Marketing Glossary/ Guerrilla Marketing Retrieved on $14^{\text {th }}$ April, 2021 from: https://www.textbroker.com/guerilla-marketing

[25] Uyanik, K. \&Guler, N. (2013). A study of multiple linear regression. Procedia-Social and Behavioural Sciences, 106, 234 240

[26] Van, D.P. (2009). What matters most in Adversity Campaigns: The Relative Effect of Media Expenditure and Message Content. Strategy International Advertising 28:669-690

[27] Zablah, A. R., Bellenger, D. N., Johnston, W.J. (2004). An evaluation of divergent perspectives on customer relationship management: Towards a common understanding of an emerging phenomenon. Industrial Marketing Management, 33 (4) $475-$ 489. 